\title{
Some Biochemical and Hematological parameters on some cases of dependence among Yemenies.
}

\author{
Nabil, H.s. ElHamady; Thabit Nasher* \\ and Rafieddin, A. AlMadi** \\ Forensic Medicine and Clinical Toxicology; Internal Medicine* departmens, Faculty of \\ Medicine and Organic Chemistry** department, Faculty of Pharmacy, Sana'a University
}

\begin{abstract}
Subjects and methods, Forty five men aging 18-45 years old were divided into three groups. Control group individuals were not suffering from dependencies. Group I and Group II, were suffering from alcohol and heroin dependenc respectively. Biochemical and hematological studies were performed before starting this trials. Results, there was high significant increase in the value of alanine aminotransferase (ALT), aspartate aminotransferase (AST) lactate dehydrogenase (LDH), alkaline phosphatase (ALP), bilirubin and uric acid in all patients in comprison to the control group. It was found that cholesterol increased in group I and decreased in group II while blood urea decreased in group I and increased in group II. Calcium and potssium decreased in both groups I and II. The increase of fasting blood sugar and creatinine in group II was highly significant while it was non significant in group I. There was high significant increase in eosinophils percentage and prothrombin time and decrease in total leucocytic count: percentage of lymphocytes, hematocrite value and hemoglobin in all patients in comparison to the controls.
\end{abstract}

\section{Introduction}

Drug dependencies are world wide problems assuming alarming proportions in Yemen over the past few years among scondary school students and university students. It was found that the great incidence of drug dependence was among failed and law standard students (Milhorn, 1999).

Physicians have daily contact with chemically dependent individuals but the majority of them deny chemical dependence, This should be considered as a symptom of the disease ( Hassan, et al 1994).

Heroin is one of the semisynthetic opioids that threats our society. It may be injected, swallowed, snorted, placed under the tongue or smoked (Hassan, M.A. et al 1994). The lifetime prevelence of alcohol abuse or dependence is $13.3 \%$ and the oneyear incidence is $1.7 \%$. The lifetime prevelance of non-alcohol drug abuse or dependence is $5.9 \%$ and the one-year incidence is approximately $1 \%$ (Kaplan \& Sadock. 1991).

The most improtant fact is, as with any chronic progressive disease, the early the diagnosis of chemical dependence, is needed for a better outcome, (Milhorn, 1999).

This work was a trial to get some laboratory values that may help to diagnose or arouse suspicion to drug dependence.

\section{Subjects and methods}

All patients examined in this study were alcoholics and heroin abusers. A total number of 45 men with age range 18-45 years old were examined. They were classified into three groups each consisting of 15 persons;

Control group : normal subjects not suffering from any dependence.

Group I : alcoholics. 
Group II : Heroin abusers.

All of these groups were subjected to psychiatric and medical examinations and laboratory evaluation. All patients were refered to Forensic Medicine and clinical toxicology department and to internal Medicine department, Faculty of Medicine \& Health Sciences Sana'a University.

Before starting the trial, blood samples were taken to study some biochemical and hematological values. The studied biochemical tests were alanine aminotransferase and aspartate aminotransferase (Retiman and Frankel, 1957), alkaline phosphatase (Babson et al, 1966) lactate dehydrogenase (Cabaud \& Wroblewski, 1958), total bilirubin (Meites., 1965), total cholesterol (Parekh \& Jung. 1970), fasting blood glucose level (Martinek. 1966), uric acid (Archibald, 1957), urea (Kaplan, 1965) creatinine (Bulter. 1976), calcium and potassium (Maas et al., 1983). Red and white blood cells were counted using an automiated cell counter (Coulter, T 660) and prothrombin was estimated according to (Dacie and Lewis, 1977).

\section{Results and Discussion}

The results of this study were represented in tables (I) and (2).

There was a high significant increase in the levels of ALT, AST, LDH, ALP, bilirubin in the two groups of alcohol and heroin dependence patients while there was high significant decrease in blood cholesterol in the heroin dependence and high significant increas in the cholesterol level of the alcoholics. Seth. (2001) and (Milhorn,1999) reported that alcoholism may be associated with elevated laboratory tests including ALT, AST, LDH, ALP and total cholesterol. They also reported that these tests are common to be elevated in other dependencies due to hepatic toxicity and injury.

The fasting blood glucose was highly significantly increased in heroin addiction and non-significantly increased in cases of alcoholics. Liepman et al (1990)., reported that alcoholics may have hypoglycaemia or hyperglycaemia as alcohol impaires gluconeogenesis so that blood glucose level fall especially in patients suffering from poor nutrition. They also reported that other dependencies e.g. opioid derivatives and substitutes may cause damage to the pancreas leading to high blood glucose level. (Milhorn, 1999) reported that opioids may produce high resting glucose level and an abnormal glucouse tolerance test. While Seth. (2001) was not in agreement as he reported that alcohol impairs hepatic gluconeogenesis resulting in hypoglycemia.

The uric acid was high significantly increased in alcoholics and in heroin addicts. These results were confirmed by Seth. (2001) who reported the uric acid showed elevated values in alcoholism, opioids and other dependencies, due to decrease their clearance.

The blood urea was high significantly decreased in alcoholics, and increased in heroin addicition. The creatinine values were not affected by alcoholic addiction while in heroin the values were high significantly increased. Milhorn (1999) reported a decrease in blood urea in alcohol addicts and increase in opioid addicts. $\mathrm{He}$ reported also that the renal dysfunction in cases of inhalants dependencies may be due to renal tubular necrosis and renal failure which cause abnormal laboratory renal values.

The calcium and potassium levels were high significantly decreased in both alcoholic and heroin dependencies. Seth. (2001) reported that vomiting which may be associated with the drug abuse or with drug withdrowal may produce electrolyte abnormalities e.g. decreased potassium, calcium, chloride magnesium and phosphorus and elevated bicarbonate and $\mathrm{pH}$ value,

There was a high significant decrease in erythrocytes, white blood cells, lymphocytic and platelet count, in hematocrite value and in hemoglobin percentage and a high significant increase in eosinophilic count in all cases of alcohol and heroin dependencies in comparison to the controls. Seth. (2001) and (Milhorn, 1999) recorded that alcohol and opioid dependencies may cause anemia, decreased white blood cell 
and platelet counts due to folic acid and vitamin B12 defeciencies and the prolonged prothrombin time occurred in alcoholism may be due to alcoholic liver disease and hepatic toxicity. Seth.(2001) seported that alcoholic abuse and opioid dependencies can derange the process by which erythocytes, leukocytes and thrombocytes mature and enter the blood stream and this results in reduction of these blood compounds and corresponding enemia, lowered resistance to disease and increased risk of the hemorrhage respectively. $\mathrm{He}$ recorded that the decreased hematocrite value and hemoglobin percentage in cases of alcoholism or other dependencies is due to pancytopenia which occurred as a result of bone marrow depression by these drugs. However (Milhorn,1999) recorded increased eosinophils in opioids addiction and normal value in alcoholism. These results were not in agreement with the present results as there was eosinophilia in both alcohol and heroin dependencies.

Table (1) : Some biochemical values in Alcohol (Ethanol) (Group 1)And Heroin (Group II) dependence patients.

\begin{tabular}{|c|c|c|c|c|c|c|c|c|c|c|c|c|}
\hline & $\begin{array}{l}\text { ALT } \\
\text { U/L }\end{array}$ & $\begin{array}{l}\text { AST } \\
\text { U/L }\end{array}$ & $\begin{array}{l}\text { LDH } \\
\text { U/L }\end{array}$ & $\begin{array}{l}\text { ALP } \\
\text { U/L }\end{array}$ & $\begin{array}{c}\text { Bilirubin } \\
\mathrm{U} / \mathrm{L}\end{array}$ & $\begin{array}{c}\text { Chclest } \\
\text { erol } \\
\mathrm{mg} / \mathrm{dL}\end{array}$ & $\begin{array}{c}\text { Fasting } \\
\text { glucose } \\
\text { mg/dL } \\
\text { level }\end{array}$ & $\begin{array}{l}\text { Uric acid } \\
\mathrm{mg} / \mathrm{dL}\end{array}$ & $\begin{array}{l}\text { Blood } \\
\text { urea } \\
\mathrm{mg} / \mathrm{dL}\end{array}$ & $\begin{array}{c}\text { creatini } \\
\text { ne } \\
\mathrm{mg} / 100 \\
\mathrm{ml}\end{array}$ & $\begin{array}{c}\text { Calcium } \\
\mathrm{mg} / \mathrm{dL}\end{array}$ & $\begin{array}{c}\text { Potass } \\
\text { ium } \\
\mathrm{mEq} / \mathrm{L}\end{array}$ \\
\hline $\begin{array}{l}\text { Control } \\
\text { gorup } \\
n=15\end{array}$ & & & & & & & & & & & & \\
\hline Range & $10-36$ & $10-40$ & $65-120$ & 13-39 & $0.3-0.09$ & $130-220$ & $70-110$ & 3.7 & $10-25$ & $0.7-1.6$ & $7.9-10.6$ & $3.9-5.1$ \\
\hline $\begin{array}{l}\text { Mean } \pm \\
\text { SE value }\end{array}$ & $29.5 \pm 1.8$ & $30 \pm 1.9$ & $53 \pm 3.7$ & $29.1 \pm 1.3$ & $0.58 \pm 0.03$ & $187 \pm 4.8$ & $90 \pm 3.6$ & $4.7 \pm 0.6$ & $18.5 \pm 0.9$ & $1.16 \pm 0.2$ & $9.29 \pm 0.6$ & $4.66 \pm 0.5$ \\
\hline$\frac{\text { Group I }}{\mathrm{n}=15}$ & $70-106$ & $75-130$ & $156-220$ & $80-120$ & $1-1.9$ & $240-6.2$ & $65-125$ & $15-55$ & $4-9$ & $0.6-1.9$ & $3.9-7$ & $1.6 \pm 3.9$ \\
\hline $\begin{array}{l}\text { Mean } \pm \\
\text { SE }\end{array}$ & $90 \pm 3.1$ & $97.5 \pm 3.0$ & $192.5 \pm 4.7$ & $96 \pm 3.6$ & $1.23 \pm 0.1$ & $305 \pm 360$ & $98.5 \pm 4.1$ & $31 \pm 2.8$ & $5.9 \pm 0.8$ & $1.36 \pm 0.15$ & $5.27 \pm 0.7$ & $2.63 \pm 0.3$ \\
\hline P. value & $-16.877^{\star *}$ & $-19.008^{* *}$ & $-16.634^{* *}$ & $-18.001^{\star *}$ & $-6.226^{* *}$ & $-15.049^{* *}$ & $\begin{array}{c}-1.558 \\
\text { N.S. }\end{array}$ & $-9.184^{\star *}$ & $10.464^{* *}$ & $\begin{array}{l}-0.800 \\
\text { N.S. }\end{array}$ & $4.360^{* *}$ & $3.481^{* *}$ \\
\hline$\frac{\text { Group II }}{\mathrm{n}=15}$ & $75-98$ & $86-130$ & $195-250$ & $70-116$ & $0.8-1.2$ & $80-115$ & $120-190$ & $8.5-25$ & $45-80$ & $4.9-9.2$ & $4.5-7.4$ & $1.4-4$ \\
\hline $\begin{array}{l}\text { Mean } \pm \\
\text { SE }\end{array}$ & $87.6 \pm 3.7$ & $107 \pm 2.9$ & $229 \pm 4.8$ & $86.5 \pm 3.6$ & $0.97 \pm 0.09$ & $100.5 \pm 3.2$ & $152 \pm 3.8$ & $14.3 \pm 1.7$ & $65 \pm 2.2$ & $11.42 \pm 1.5$ & $5.95 \pm 0.9$ & $2.35 \pm 0.4$ \\
\hline P. value & $-14.169^{\star *}$ & $-22.209^{* *}$ & $-22.440^{* *}$ & $-14.997^{\star *}$ & $-4.111^{* *}$ & 14.994 & $-11.844^{\star *}$ & $-5.325^{\star \star}$ & $-19.563^{\star *}$ & $-6.78^{\star \star}$ & $3.088^{* *}$ & $3.608^{* *}$ \\
\hline $\begin{array}{l}\text { P. value of } \\
\text { Group I } \\
\text { vs. } \\
\text { Group II }\end{array}$ & 0.456 & -2.277 & $-5.433^{\star}$ & $2.239^{\star}$ & $\begin{array}{l}1.933 \\
\text { N.S. }\end{array}$ & $29.310^{* *}$ & $\begin{array}{l}9.570^{* *} \\
\end{array}$ & $5.098^{\star \star}$ & $--25.246^{\star *}$ & $-6.673^{\star \star}$ & $\begin{array}{l}-0.596 \\
\text { N.S. }\end{array}$ & $\begin{array}{l}0.560 \\
\text { N.S. }\end{array}$ \\
\hline
\end{tabular}


Table (2) : Some hematological values in alcohol (ethanol) (Group I) And heroin (Group II) in dependence patients.

\begin{tabular}{|c|c|c|c|c|c|c|c|c|}
\hline & $\begin{array}{l}\text { Red Blood } \\
\text { cells } \\
\text { Million } / \mathrm{mm}^{3} \\
\end{array}$ & $\begin{array}{c}\text { White } \\
\text { blood cells } \\
1000 / \mathrm{mm}^{3}\end{array}$ & $\begin{array}{c}\text { Lymphocytes } \\
\%\end{array}$ & $\begin{array}{c}\text { Eosinophils } \\
\%\end{array}$ & $\begin{array}{c}\text { Throbocytes } \\
1000 / \mathrm{mm}^{3}\end{array}$ & $\begin{array}{c}\text { Hematocrits } \\
\%\end{array}$ & $\begin{array}{c}\mathrm{Hb} \\
\text { g./dL }\end{array}$ & $\begin{array}{c}\text { Prothrombin } \\
\text { Time } \\
\text { (seconds) }\end{array}$ \\
\hline \multicolumn{9}{|l|}{$\begin{array}{c}\text { Control } \\
\text { group } \\
n=15\end{array}$} \\
\hline Range & $4.5-6.5$ & $4-10$ & $12-40$ & $0-5$ & $150-300$ & $42-52$ & $13-17$ & $11-15$ \\
\hline Mean \pm SE & $5.2 \pm 0.3$ & $8.2 \pm 0.5$ & $25 \pm 1.1$ & $2 \pm 0.15$ & $140 \pm 6.3$ & $47 \pm 1.7$ & $15.2 \pm 0.7$ & $13.3 \pm 0.6$ \\
\hline \multicolumn{9}{|l|}{$\frac{\text { Group I }}{n=15}$} \\
\hline Range & $2.5-4.1$ & $2.5-5$ & $8 .-18$ & $10-50$ & $80-150$ & $12-35$ & $4-10$ & $16-25$ \\
\hline Mean \pm SE & $3.4 \pm 0.3$ & $3.6 \pm 0.3$ & $11 \pm 0.7$ & $22 \pm 1.1$ & $115_{ \pm} 4.9$ & $20.5 \pm 1.3$ & $7.4 \pm 0.6$ & $20 \pm 1.1$ \\
\hline P. value & $4.243^{* *}$ & $7.889^{* \star}$ & $10.738^{* *}$ & $-18.015^{\star \star}$ & $15.662^{\star *}$ & $12.383^{* *}$ & $8.460^{* *}$ & $-5.347^{* *}$ \\
\hline \multicolumn{9}{|l|}{$\frac{\text { Group II }}{n=15}$} \\
\hline Range & $2.1-3.2$ & $2-15$ & $6-30$ & $12-15$ & $80-150$ & $8-30$ & $4-11$ & 18-32 \\
\hline Mean+SE & $2.9+0.2$ & $6.9+0.4$ & $14 \pm 0.8$ & $22+1.2$ & $106 \pm 4.3$ & $16.5+1.1$ & $7.2 \pm 0.5$ & $24+1.2$ \\
\hline P. value & $6.379^{* *}$ & $2.030^{*}$ & $8.087^{\star *}$ & $-16.538^{\star *}$ & $17.568^{\star \star}$ & $5.063^{\star \star}$ & $9.300^{* *}$ & $-7.975^{\star \star}$ \\
\hline $\begin{array}{l}\text { P. value of } \\
\text { Group I vs. } \\
\text { Group II }\end{array}$ & 1.387 & $-6.600^{* *}$ & $-2.822^{* *}$ & $\begin{array}{l}\text { Zero } \\
\text { N.S. }\end{array}$ & $\begin{array}{l}1.381 \\
\text { N.S. }\end{array}$ & $2.349^{*}$ & $\begin{array}{l}0.256 \\
\text { N.S. }\end{array}$ & $-2.457^{\star}$ \\
\hline
\end{tabular}

\section{References}

1. Archiblad, RM (1957): Clin. Chem. 3 : 102.

2. Babson, Al; Grelly, S.; Coleman CM and Phillips, G.E. (1966): Clin. Chem., 12 : 482.

3. Bulter, A.R. (1976): Clin. Chem. Acta, 59 : 227.

4. Cabaud, PG and Wrablewski, F. (1958): Am. J. Clin. Pathol. 30 : 234.

5. Dacie, J.V. and Lewis, S.M. (1977): Practical hematology Chapter $13.5^{\text {th }}$ ed. Churchill, London.

6. Hassan, M.A., Khalil O, Laila H.F. and Attia, H.M. (1994), Bio chemical \& Hematological study on some cases of drug dependenies The New EGYPTIAN Journal of Medicine Vol. 10 No :1 January .

7. Kaplan. A. (1965): Urea nitrogen and urinary ammonia. Standard methods of clinical chemistry. Meites S (ed). Academic Press New York.

8. Kaplan. HI and Sadeck, B.j. (1991): Psychoactive substances induced organic mental disorders and Psychoactive substance use disorders. Synepsis of psychiatry $6^{\text {th }}$ ed.

9. Liepman,WR; Anderson, RC, and Fisher, JV (eds) (1990): Family Medicine
Curriculum Guide to substance abuse. Society of Teachers of Family Medicine. Kansas City. Missouri.

10. Maas, AHR; Kofslad, J. and Siggaard Andersen (eds)(1983): Ionized calcium, sodium and potassium by ion selective Electrodes Vol. 5. Proceedings of the first meeting of the European working group on ion selective electrodes. IFCC workshop, Oslo.

11. Martinek, RG (1966): Clin. Chem.. 12: 541.

12. Meites. S. (ed.) (1965): Recommendation on a uniform Bilirubin standard. Standard Methods of Clinical Chemistry. Academic Press, New York.

13. Milhorn. HT (1999): The diagnosis of alcoholism and other dependencies. In: Review course syllabus American Medical Society on Alcoholism and other drug dependencies. New York.

14. Parekh, AC and Jung, DH (1970): Anal Chem. 42: 1423.

15. Reitman, S. and Frankel, S. (1957): Am. J.Clin. Pathol. 28: 56.

16. Seth, S. (2001) Medical Toxicology part II Section C Alcohols \& drugs, of abuse p 155- $160 \&$ from 201-208. 


\section{بعض القياسات الكيميائية والدموية لبعض حالات الإدمان بين اليمنيين}

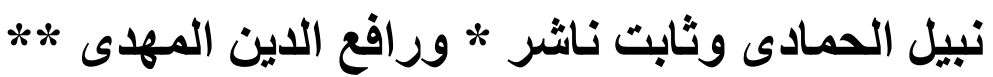

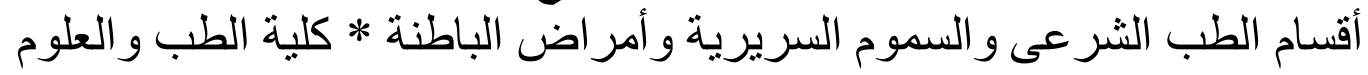

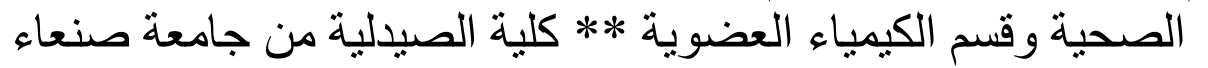

تم إجر اء هذا البحث على خمسة وأربعين رجلاً ينر اوح أعمار هم بين 18 إلى

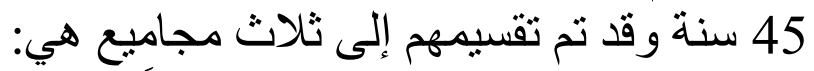
الجموعة الضابطة : عددهم 15 رجلاً لا يعانون من ألى ألى إدمان.

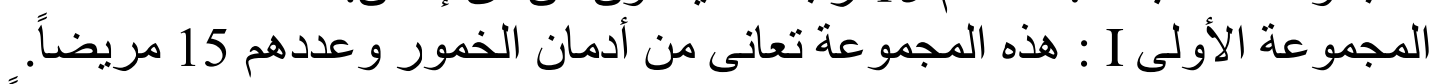

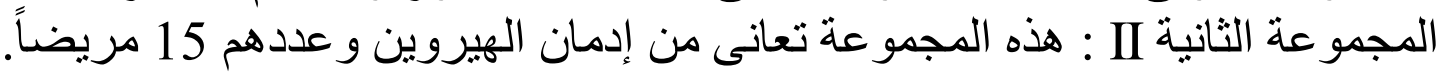

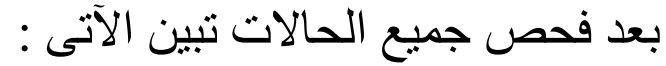

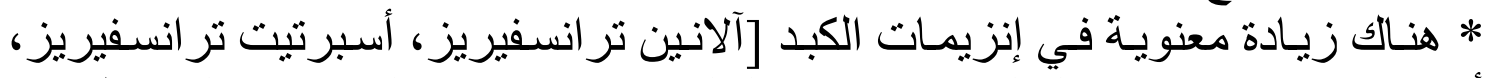

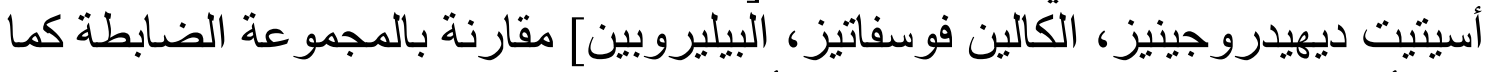

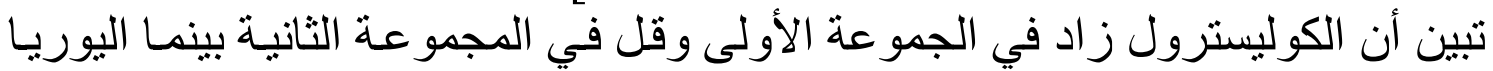

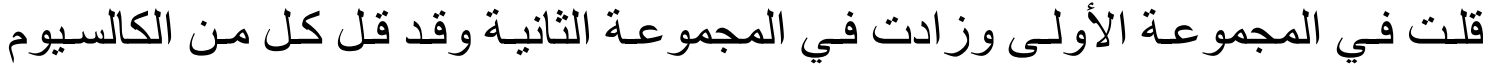

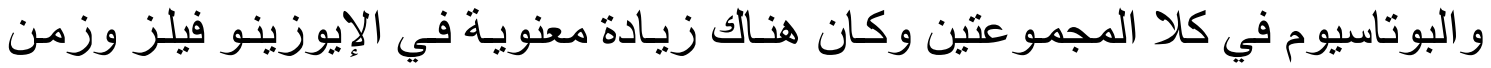

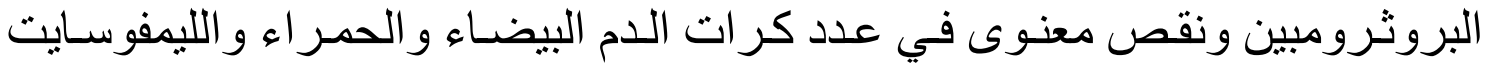
و القيمة الهيماتوكريتية و اليمو جلوبين في كلا الهجمو عتين مقارنة بالمجمو عة الضابطة. 